Pertanggalan Absolut Situs Kubur Kalang : Signifikasinya Bagi Periodisasi Kubur Peti Batu Di Daerah Bojonegoro Dan Tuban, Jawa Timur

\title{
Retno Handini
}

Keywords: burials, chronology, history, periodization, prehistory

\section{How to Cite:}

Handini, R. (2003). Pertanggalan Absolut Situs Kubur Kalang : Signifikasinya Bagi Periodisasi Kubur Peti Batu Di Daerah Bojonegoro Dan Tuban, Jawa Timur. Berkala Arkeologi, 23(2), 24-38. https:// doi.org/10.30883/jba.v23i2.873
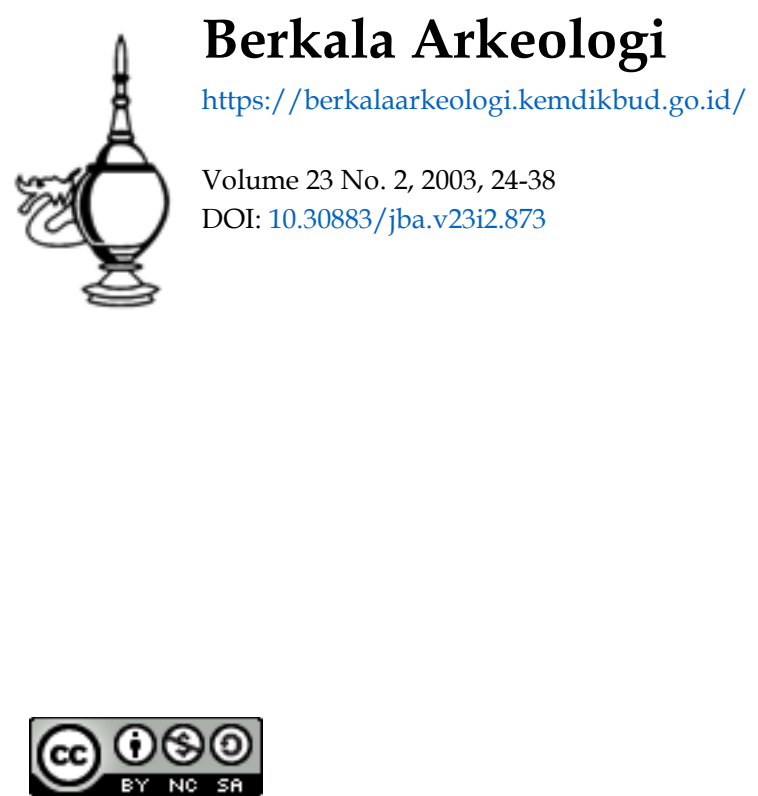

This work is licensed under a Creative Commons Attribution-NonCommercial-ShareAlike 4.0 International License. 


\title{
PERTANGGALAN ABSOLUT SITUS KUBUR KALANG : SIGNIFIKASINYA BAGI PERIODISASI KUBUR PETI BATU DI DAERAH BOJONEGORO DAN TUBAN, JAWA TIMUR
}

\author{
Retno Handini
}

$\mathbf{P}$ endahuluan

Kubur peti batu (stone cist grave) merupakan salah satu bentuk budaya penguburan tradisi prasejarah yang terkait dengan budaya megalitik, khususnya dengan gelombang migrasi megalitik muda. Distribusi temuan peti kubur batu di Indonesia cukup luas, yang mencakup beberapa daerah di Pulau Jawa (Bojonegoro, Tuban, Gunung Kidul, dan Kuningan) dan di Sumatra (Pasemah). Penelitianpenelitian mendalam terhadap peti kubur batu tersebut memberikan suatu pemahaman yang signifikan, bahwa kubur-kubur itu tidak hanya didirikan pada periode perundagian, tetapi sebagian besar justru dibangun pada periode sesudahnya. Sebagai contoh, peti kubur batu di Gunung Kidul paling tidak masih dibangun hingga akhir abad 14 Masehi (Hoop, 1935).

Di Jawa Timur, kubur peti batu banyak ditemukan di daerah Bojonegoro dan Tuban. Di Kecamatan Malo (Bojonegoro), pada petak 68 dan 69 dalam wilayah BKPH Malo, telah ditemukan tidak kurang dari 15 buah peti kubur batu, yang terdapat di tengahtengah hutan jati. Demikian pula di petak 24 dan 27, ditemukan setidaknya 19 buah peti kubur batu. Sementara di petak 70, masih terdapat 2 buah temuan sejenis. Beberapa buah kubur batu yang terdapat di Desa Kawengan dan Kidangan telah digali oleh Balai Arkeologi Yogyakarta, yang menghasilkan temuan sisa rangka manusia dan bekal kuburnya berupa periuk, perhiasan (gelang dan cincin emas), maupun senjata-senjata besi (Widianto et al., 1990). Di Kecamatan Senori (Kabupaten Tuban) yang masih terkait dengan BKPH Malo, ditemukan pula 2 buah peti kubur batu di Desa Banyuurip, dalam petak 30.

Hampir semua kubur-kubur ini berorientasi chtonis, yaitu barat-timur dengan letak kepala berada di bagian timur. Segala aspek yang tercermin dalam teknik penguburan pada kubur batu mengacu pada teknik penguburan masa megalitik, yang didukung antara lain lokasi kuburan pada daerah-daerah yang tinggi. Tradisi lesan setempat yang masih hidup hingga saat ini menyebutkan bahwa kubur-kubur peti batu tersebut merupakan kuburan orang Kalang, sehingga di Kabupaten Bojonegoro dan Kabupaten Tuban, orang-orang menyebutnya sebagai Kubur Kalang.

Kisah mengenai kelompok etnis orang Kalang sangat menarik untuk dicermati kembali. Kata atuha kalang yang terdapat pada kitab Negarakrtagama, mempunyai arti orang yang diserahi tugas untuk mengelola hutan. Nama Kalang hingga saat ini 
masih dipakai untuk menyebut sekelompok orang, yang masih dapat dijumpai di daerah Pekalongan, Tegal (mendiami Desa Ketitang dan Kalang), dan Kotagede (mendiami daerah Tegalgendu). Pada masa Sultan Agung sekitar tahun 1640, OrangOrang Kalang dikumpulkan dari berbagai tempat dan diberi wilayah tersendiri di Tegalgendu.

Eksistensi Orang Kalang memang benar-benar ada, saat ini Orang Kalang telah hidup berinteraksi dengan komunitas lainnya. Secara lebih spesifik, perkampungan Orang Kalang dapat ditemukan di daerah Pekalongan dan Tegal. Di daerah Bojonegoro dan Tuban dimana saat ini banyak ditemukan kubur peti batu yang diyakini sebagai kubur orang Kalang, eksistensi orang Kalang sendiri masih belum jelas.

Dalam kerangka penelitian arkeologi, berbagai survei dan ekskavasi tentang peti kubur batu telah banyak dilakukan di berbagai daerah, baik di Jawa maupun Sumatra. Pada dekade 1980an, Balai Arkeologi Yogyakarta telah melaksanakan berbagai ekskavasi peti kubur batu di daerah Jawa Timur. Hasil-hasil penelitian tersebut telah mampu memberikan gambaran tentang eksistensi peti kubur batu di Bojonegoro dan Tuban, baik yang menyangkut konstruksi pembangunannya, konsep religi yang mendasari pada jamannya, maupun teknik-teknik penguburan yang pernah dilakukan dari himpunan budaya arkeologis-megalitik tersebut (Widianto et al., 1990). Di lain pihak, penulis telah melakukan penelitian etnografi tentang religi kematian dan tata cara penguburan dari suatu komunitas yang masih hidup saat ini dan diduga mempunyai keterkaitan dengan kubur kalang, yakni komunitas orang Samin yang saat ini hidup di daerah hutan jati Bojonegoro, Tuban, dan Blora serta komunitas Orang Kalang. Hasil penelitian kami menunjukkan bahwa konsep religi kematian dan proses penguburan pada kubur kalang sangat berbeda dengan yang terjadi pada masyarakat Kalang dan Samin, sehingga tidak terdapat keterkaitan sama sekali antara kubur kalang dengan masyarakat yang masih hidup saat ini (Handini et al., 2003). Dengan perkataan lain, kubur-kubur peti batu yang dikenal dengan istilah kubur kalang tersebut merupakan hasil budaya sekelompok masyarakat tertentu yang pernah hidup di sekitar lokasi kubur, dimana saat ini kelompok tersebut telah benar-benar lenyap.

Oleh karena itu, masih terdapat berbagai pertanyaan penting yang harus dijawab: kapan budaya kubur kalang tersebut dibangun? Apakah budaya tersebut merupakan budaya prasejarah "murni" yang tercipta pada periode prasejarah, ataukah merupakan suatu tradisi prasejarah yang mampu menembus batas teoritis ? Siapakah pendukung budaya kubur kalang di Bojonegoro ? Tulisan ini akan berupaya menjawab pertanyaan-pertanyaan tersebut di atas, terutama atas hasil uji pertanggalan absolut terhadap sisa manusia dari hasil ekskavasi Kotak 18, Sektor X, Situs Kawengan (Bojonegoro), melalui metode Carbon-14. Sebelum sampai pada interpretasi, akan diberikan uraian mengenai budaya kubur kalang, baik secara budaya fisiknya maupun 
konsepsi religinya, untuk memberikan gambaran yang lebih lengkap tentang budaya kubur kalang.

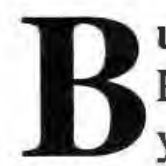
udaya Kubur Kalang di Bojonegoro dan Tuban

Penamaan kubur peti batu sebagai Kubur Kalang hanya berkonotasi lokal saja, yang berasal dari masyarakat di daerah Bojonegoro dan Tuban. Istilah kubur kalang sejauh ini belum ditemukan di daerah lain di luar Kabupaten Tuban dan Bojonegoro. Hal ini berarti bahwa sebutan Kubur Kalang hanya merupakan sebutan lokal, dan bukan merupakan istilah umum yang dapat ditemukan di berbagai daerah.

\section{Kubur Kalang Secara Budaya Fisik}

Kubur peti batu adalah kubur berbentuk liang lahat yang terdiri dari lantai, empat buah dinding batu, dan tutup peti, yang dibuat dari batu pipih (Ayatrohaedi et al., 1981). Konstruksi kubur yang demikian tersebut biasanya disusun dari lempenganlempengan batu tipis (slab-stone) yang berbahan batu pasir gampingan (limestoneous sand-stone), dalam arti bahwa masing-masing dasar, tutup, dan keempat dinding kuburnya terdiri satu lempengan batu atau lebih.

Seluruh kubur peti batu yang ditemukan di daerah Bojonegoro dan Tuban, menunjukkan bahan dasar yang sama, yaitu batu pasir gampingan (limestonous sand stone). Materi dasar yang dipakai untuk penyusunan kubur di kedua daerah tersebut adalah lempengan-lempengan batu (slab stone) yang merupakan bentukan alam. Asumsi ini didasarkan pada temuan lempengan-lempengan batu putih yang terdapat di sekitar Situs Kidangan, Kawengan, dan Gunung Sigro, yang masih dapat dilihat pada singkapan tebing perbukitan, dan belum dimanfaatkan oleh manusia. Lempengan batu tersebut sudah terbentuk dan berupa bongkahan di antara matriks yang berupa lempung pasir krikilan. Pada stratigrafi yang tampak di beberapa singkapan tebing perbukitan, ketebalan lempengan tersebut telah terstruktur antara $10-25 \mathrm{~cm}$, yang nampak sebagai salah satu komponen perlapisan singkapan. Lokasinya antara lain dapat dilihat di singkapan jalan dari Situs Kidangan ke arah Wonocolo/Banyuurip, pada jarak sekitar 3 kilometer di sebelah barat pertigaan Situs Kidangan. Pada lokasi ini, lempengan-lempengan batu penyusun kubur peti batu tersebut dapat dilihat dengan jelas dalam susunan berlapis. Di situs Gunung Sigro, lokasi bahan yang sama ditemukan di berbagai tempat dalam singkapan yang terdapat di sekitar situs, dalam struktur berlapis seperti yang ditemukan dalam sumber bahan dari Situs Kidangan. Kuat dugaan bahwa lokasi-lokasi tersebut merupakan sumber bahan penyusunan kubur peti batu di ketiga situs. Bahan dasar tersebut tidak didatangkan dari luar daerah, tetapi ditambang di daerah setempat, sekitar lokasi kubur. Jarak antara lokasi penambangan bahan dasar dengan lokasi kubur umumnya antara 500 meter hingga 3 kilometer. Jarak tersebut mengidikasikan lokasi penambangan dan lokasi pemakaian. 
Konstruksi kubur peti batu di ketiga situs tersebut umumnya sama, yaitu terdiri atas dasar/lantai, empat buah dinding, dan tutup kubur. Di Situs Kidangan dan Kawengan sebagian masih menunjukkan unsur-unsur tutup kubur, walaupun dalam kondisi rusak berat. Dinding-dinding kubur didirikan pada keempat sisinya, pada umumnya terdiri dari lebih satu lempengan. Antara satu dinding dengan dinding lainnya kadang-kadang ditemukan batu-batu yang berukuran kecil, yang melekat pada dinding, mungkin dipakai sebagai penguat berdirinya dinding.

Dengan mengacu pada gejala konstruksi dinding seperti ini, maka cara pembangunan kubur peti batu di daerah Bojonegoro dan Tuban mempunyai kemiripan dengan kontruksi peti kubur batu di Wonosari maupun Kuningan. Keberadaan batu-batu penyangga tersebut mungkin mengarah pada teknik sponningen, yakni teknik membangun pada keempat sudut yang bertujuan untuk memperkuat berdirinya dinding kubur, agar tidak roboh ke bagian dalam kubur (Sukendar, 1976)

Data yang dihimpun dalam ekskavasi yang telah dilakukan oleh Balai Arkeologi Yogyakarta (Widianto et al., 1990) menunjukkan teknik penguburan yang seragam, yaitu penguburan primer (primary burial) dengan orientasi timur-barat. Konsepsi chtonis menganggap bahwa arah timur merupakan arah matahari terbit dan awal mula kehidupan, sementara arah barat merupakan arah matahari tenggelam dan akhir kehidupan. Hal ini menjelaskan posisi mayat dalam orientasi kembali suci seperti ketika lahir.

Hasil analisis komponen rangka menunjukkan jumlah individu yang dikubur dalam satu kubur berkisar antara 1, 2, dan 5 orang. Keadaan ini menimbulkan dugaan bahwa kubur-kubur tersebut tidak dipakai sebagai kubur tunggal dalam sekali penguburan. Dalam kasus kematian normal, jarang dijumpai dua atau bahkan lima individu mati dan dikuburkan bersama-sama. Dengan berdasarkan jumlah individu yang lebih dari satu untuk sebagian besar kubur di ketiga situs, maka ditafsirkan bahwa kubur-kubur tersebut digunakan untuk menguburkan beberapa individu yang mati tidak dalam waktu bersamaan. Ada kemungkinan bahwa antara satu individu dengan individu lainnya yang terdapat dalam satu kubur berasal dari lingkungan keluarga sendiri. Data penguburan ini menjelaskan bahwa teknik penguburan yang dipakai di Bojonegoro dan Tuban adalah penguburan primer, yang sebagian besar berupa penguburan ganda.

Bentuk tengkorak menunjukkan brachycephal, dengan kedua dinding parietal yang relatif melebar pada daerah parietal bagian atas, bagian occipital datar, muka yang sama sekali tidak mengesankan prognatisma, ukuran gigi yang tidak terlalu besar, dan tulang-tulang panjang anggota tubuh yang tidak mengesankan kekar. Memang ada perbedaan ukuran tulang antar individu, tetapi perbedaan tersebut hanya disebabkan oleh perbedaan jenis kelamin. Oleh karena itu, dengan mengacu pada karakter kuat yang dapat diberikan oleh komponen tengkorak, maka identifikasi ras manusia dari 
berbagai kubur peti batu di Tuban dan Bojonegoro adalah Mongolid (Widianto et al., 1990: Handini et al., 2003).

Unsur-unsur artefak lain juga ditemukan dalam kubur peti batu dalam kuantitas yang minim antara lain perhiasan emas dan alat keperluan sehari-hari seperti gerabah dan senjata besi. Secara kualitas keberadaan artefak tersebut memberikan informasi yang sangat penting, karena jika dikaitkan dalam konteks kubur, maka data artefaktual tersebut dapat dikategorikan sebagai bekal kubur.

Dengan mengacu pada data yang diperoleh dari observasi terhadap Kubur Kalang tersebut diperoleh pamahaman bahwa budaya ini jelas-jelas tidak menyimpang sama sekali dari budaya kubur peti batu sebagai suatu budaya yang berakar pada budaya gelombang megalitik muda. Ini berarti bahwa, apa yang didefinisikan sebagai "kubur peti batu" dari budaya megalitik muda tersebut secara fisik dapat dikenali lagi pada Kubur Kalang, dan sama sekali tidak menunjukkan perbedaan antara keduanya. Dengan lain kata, Kubur Kalang identik dengan kubur peti batu sebagai salah satu jenis budaya megalitik muda.

\section{Konsep Religi pada Kubur Kalang}

Konsep religi dan penguburan pada Kubur Kalang ini secara jelas dapat ditemukan dari berbagai aspek yang melatarbelakangi eksistensinya. Data distribusi kubur-kubur ini menunjukkan persebaran yang berada di tengah hutan jati, yang secara umum berada di berbagai puncak perbukitan. Oleh karena itu, penempatan kompleks kubur pada tempat-tempat yang tinggi merupakan salah satu karakter yang menonjol dan bermakna, yang sangat relevan dengan eksistensi Kubur Kalang sebagai suatu ekspresi budaya berciri megalitik. Secara umum penempatan bangunan megalitik dalam suatu tempat yang tinggi sangat berkaitan dengan konsep gunung sebagai tempat abadi para leluhur, sehingga konsepsi seperti ini juga melandasi konsep dasar penempatan Kubur Kalang sebagai tempat sakral setelah kematian (life after death).

Aspek kedua adalah orientasi kubur yang menganggap arah tertentu sebagai arah sakral, dalam hal ini adalah arah timur dan barat. Mayoritas kubur yang masih dapat dikenali orientasi rangkanya menunjukkan penempatan kepala di bagian timur, dan kaki di bagian barat. Situasi ini mengingatkan pada arah matahari terbit dan tenggelam, sehingga arah timur disimbolkan sebagai arah kelahiran dan arah barat sebagai arah kematian. Dengan mengorientasikan posisi rangka manusia ke kedua arah tersebut, maka diidentikkan bahwa individu yang dikuburkan telah benar-benar menjalani suatu kehidupan yang penuh selama di dunia. Posisi keadaan suci dilambangkan dengan meletakkan kepala di arah timur, sebagai arah kelahiran. Hal ini mempunyai dua makna, yaitu akan berstatus sebagai individu yang suci ketika meninggal seperti halnya ketika dilahirkan, dan berstatus individu yang suci pula 
ketika memulai hidup di dunia baru. Konsepsi megalitik selalu mengajarkan bahwa kehidupan yang abadi adalah kehidupan setelah mati di dunia arwah. Oleh karena itu, orientasi kubur maupun individu si mati sinkron dengan status kubur sebagai jenis budaya megalitik.

Aspek ketiga, adalah penyertaan bekal kubur dalam suatu penguburan. Analogi etnografi pada kelompok masyarakat etnis, antara lain di Sumba mensyaratkan pemberian bekal kubur yang berupa peralatan dan perhiasan, seperti yang ditemukan di sebagian Kubur Kalang. Identifikasi terhadap eksistensi bekal kubur ini menunjukkan adanya 2 jenis bekal kubur, yaitu sebagai peralatan sehari-hari (senjata logam dan gerabah), dan sebagai perhiasan (baik emas maupun batu : cincin, gelang, manik-manik). Dua jenis bekal kubur ini pun mempunyai makna yang berbeda. Senjata logam dan gerabah merupakan alat sehari-hari yang bersifat praktis, teknofak, sementara unsur perhiasan merupakan benda sosiofak, berkonteks simbol status sosial. Oleh karena itu, dua jenis bekal kubur ini mengisyaratkan akan ditempuhnya kehidupan lain setelah alam fana ini dengan peralatan sehari-hari yang disertakan, sekaligus melambangkan status sosial si mati. Konsepsi ini sangat kental nuansanya bagi konsep megalitik, yang berakar pada pandangan-pandangan kekuatan supranatural.

Proses penguburan yang dilakukan terhadap kelompok Kubur Kalang ini menunjukkan proses penguburan primer, dengan individu ganda untuk sebagian besar kubur. Identifikasi terhadap sisa-sisa rangka manusia menjelaskan kubur komunal, yakni satu kubur dapat dipakai untuk 2-5 individu, dengan jenis kelamin laki-laki dan perempuan, dewasa maupun anak-anak. Situasi seperti ini memberikan penafsiran bahwa kubur-kubur tersebut sebagian telah dipakai sebagai kubur keluarga, yang mungkin demi efisiensi dipakai berkali-kali dalam masa yang berbeda. Hal ini didasarkan pada logika bahwa sangat tidak mungkin 5 individu dari suatu keluarga akan mati pada saat yang sama, tetapi lebih mengarah pada pemakaian kubur yang sama bagi beberapa individu yang mati dalam saat berbeda. Mengingat individuindividu tersebut masih dapat ditemukan dalam kubur yang sama, maka ketika terjadi peristiwa kematian, si mati akan dikubur pada suatu kubur yang telah dipakai sebelumnya, tanpa sama sekali memindahkan jasad dari individu pendahulunya. Analogi etnografi pemakaian kubur batu komunal sampai saat ini masih bisa kita lihat antara lain pada pemakaian sarkofagus atau kubur-kubur modern di Pulau Samosir, dimana kubur-kubur tersebut cenderung lebih digunakan sebagai kubur sekunder (Handini 1998).

Dengan mendasarkan diri pada beberapa pandangan konsep religi di atas, maka dapat ditarik suatu pemahaman bahwa eksistensi Kubur Kalang yang terdapat di Situs Kidangan, Kawengan, dan Gunung Sigro tersebut merupakan refleksi kubur dari sekelompok masyarakat yang masih menganut pandangan kekuatan supra-natural 
yang manjadi basis dalam konsepsi megalitik. Letak kubur di daerah perbukitan, orientasi kubur dan rangka manusia ke arah timur-barat, dan pemberian bekal kubur sebagai bekal untuk menempuh kehidupan abadinya dan sebagai penunjuk status sosial merupakan konsep-konsep budaya megalitik. Praktek-praktek penguburan primer dan ganda merupakan segi-segi teknis penguburan untuk efisiensi dan pembatasan ruang semata, tanpa sama sekali mengaburkan konsepsi religi megalitik yang dianut.

\section{D} ertanggalan Relatif dan Absolut Budaya Kubur Kalang

Aspek pertanggalan dari kubur-kubur peti batu di tiga situs tersebut dapat dibahas dari 2 segi pertanggalan, yaitu pertanggalan relatif dan absolut. Dalam hal ini, pertanggalan relatif akan didasarkan pada ciri-ciri budayanya, dengan mengkaitkan pada proses persebaran budaya tersebut secara teoritis. Di lain pihak, pertanggalan absolut didasarkan metode Carbon-14, dengan memakai sampel tulangtulang sisa rangka manusia dari kubur di Kotak 18, Sektor X, Situs Kawengan, Bojonegoro. Hasil pertanggalan absolut nantinya akan dapat digunakan untuk crosscheck dan verifikasi hasil pertanggalan relatif.

\section{Pertanggalan Relatif}

Teknik penguburan dengan menggunakan kubur peti batu telah dikenal luas sebagai sebuah teknik penguburan yang berkonotasi budaya megalitik. Dalam gelombang migrasi budaya megalitik, terdapat suatu formulasi yang masih diyakini sampai sekarang, bahwa gelombang migrasi budaya megalitik tua yang terjadi sekitar 2.500$1.500 \mathrm{BC}$ mengenalkan budaya batu besar yang berkonotasi simbol-simbol seperti menhir, punden berundak, dolmen non-kubur, kursi batu, jalan batu, dan sebagainya (Geldern, 1945). Jenis budaya ini tidak pernah dipakai dalam keperluan praktis, tetapi lebih banyak diciptakan sebagai benda ideofak. Di lain pihak, gelombang megalitik muda yang terjadi pada periode budaya Dongson sekitar 500 BC di awal Jaman Perundagian, mengenalkan berbagai budaya yang lebih ditujukan untuk keperluan praktis, yang sebagian besar berkonteks kubur, misalnya kubur peti batu, dolmen kubur, sarkofagus, maupun tempayan kubur. Karena kemunculannya yang kira-kira sejaman dengan Masa Perundagian, dan terutama setelah bersentuhan secara kuat dengan Jaman Besi, maka banyak di antara kubur-kubur tersebut ditemukan pula berbagai artefak logam, utamanya senjata-senjata besi. Oleh karena itu, dengan mengacu pada gelombang migrasi dan jenis budaya yang dikenalkan tersebut, dapat diketahui bahwa kubur peti batu merupakan salah satu jenis budaya megalitik muda, paling tua muncul pada $500 \mathrm{BC}$.

Satu hal yang dapat dipertanyakan di sini adalah: apakah kubur peti batu yang terdapat di Bojonegoro dan Tuban ini berasal dari periode tersebut, sebagai suatu budaya 
megalitik murni ? Atau merupakan suatu tradisi budaya yang tetap dipertahankan ciri megalitiknya, sementara periodisasinya justru telah memasuki masa sejarah ? Apabila dilihat pada bekal kubur yang disertakan, maka akan dijumpai benda-benda sebagai berikut : senjata besi, perhiasan emas dan batu berupa cincin, gelang, dan manikmanik, maupun gerabah. Dua kategori bekal kubur dapat dipisahkan, yaitu bekal kubur sebagai peralatan (gerabah dan senjata besi) dan bekal kubur sebagai asesoris berupa perhiasan. Arti dari kedua jenis bekal kubur ini adalah alat untuk melangsungkan kehidupan di alam baka, dan sebagai piranti penunjuk status sosialnya.

Berdasarkan jenis bekal kubur tersebut, maka periodisasi relatif dari kubur peti batu tersebut dapat ditafsirkan, meski dalam rentang waktu yang cukup panjang. Gerabah telah muncul sejak akhir neolitik dan besi baru menjadi ciri budaya sejak awal masehi. Oleh karena itu, pertanggalan relatif dari kubur kalang tersebut secara periode hanya dapat ditafsirkan paling tua berasal dari masa menjelang tarih Masehi, dan tidak dapat diidentifikasi periode paling mudanya. Hal ini berarti bahwa usianya dapat mewakili budaya megalitik muda mumi, tetapi juga dapat lebih muda lagi, atau bahkan merupakan suatu tradisi yang telah masuk dalam jaman sejarah.

\section{Pertanggalan Absolut Kubur Kalang}

Pertanggalan absolut dilakukan melalui metode carbon-14, dengan sampel pertanggalan menggunakan fragmen tulang panjang manusia dari Kotak 18, Sektor X, Situs Kawengan, Bojonegoro. Pemakaian tulang sisa rangka tersebut didasarkan pada kematian individu manusianya, sehingga hasil yang diperoleh dari uji pertanggalan ini akan menunjuk langsung pada pendukung budaya kubur peti batu, dan akan sangat representatif untuk menunjuk usia absolut budaya kubur itu sendiri. Hasil yang diperoleh dari uji pertanggalan carbon-14 ini adalah : $410 \pm 80$ BP (1950), sehingga menunjuk pada kisaran angka antara 330 tahun (minimal) dan 490 tahun (maksimal, dihitung hingga tahun 1950). Hal ini berarti bahwa hingga tahun 2000, kubur kalang telah berusia minimal 380 tahun dan maksimal 540 tahun. Oleh karenanya, ditafsirkan bahwa budaya kubur kalang di Bojonegoro, diciptakan oleh masyarakat pendukung budayanya pada periode antara tahun $1460 \mathrm{AD}$ dan tahun $1620 \mathrm{AD}$.

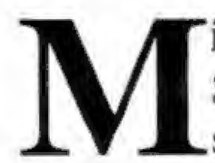

\section{isteri Kubur Kalang}

Suatu pertanyaan yang sangat relevan untuk dijawab di sini adalah: siapakah mereka yang dikuburkan di kompleks Kubur Kalang di daerah Bojonegoro dan Tuban itu ? Di manakah tempat permukiman pendukung budaya Kubur Kalang ? Bagaimana mereka membangun kubur-kubur mereka? 
Dalam tradisi lesan mengenai kubur tersebut, penamaan Kubur Kalang merupakan istilah lokal, dimana penduduk menyebut kubur peti batu sebagai kuburnya Orang Kalang. Istilah kubur kalang sendiri tidak ditemukan padanannya di luar Kabupaten Tuban dan Bojonegoro. Eksistensi Orang Kalang memang sangat nyata, hanya saja data yang dihimpun sejauh ini menunjukkan permukiman yang tersebar di pantai utara antara Brebes hingga Semarang, dan bagian selatan Jawa antara Banyumas hingga Yogyakarta. Di daerah sebaran Kubur Kalang, belum dijumpai adanya komunitas orang Kalang yang selama ini telah diketahui eksistensinya, antara lain hingga periode Majapahit, lewat berbagai prasasti yang ditemukan. Akan halnya komunitas Orang Kalang di Kabupaten Bojonegoro dan Tuban, belum dapat diidentifikasi hingga saat ini.

Dalam berbagai pengumpulan data, baik berdasarkan literatur maupun wawancara dengan penduduk sekitar kompleks Kubur Kalang tidak mampu mengidentifikasi adanya komunitas Orang Kalang pada masa sekarang maupun pada masa lalu. Tidak terdapat data arkeologis maupun tradisi oral yang dapat memberikan keterangan tentang permukiman Orang Kalang yang kuburnya ditemukan sebagai Kubur Kalang saat ini. Tidak ada keterangan pasti mengenai siapa mereka, sehingga sejauh ini menunjukkan hasil yang nihil untuk menarik hubungan antara Kubur Kalang dengan komunitas Kalang yang pernah ada dan masih dikenal hingga saat ini. Demikian pula di lokasi Kubur Kalang, tidak terdapat adanya data arkeologis, etnografis, maupun tradisi oral yang dapat mempertemukan antara Kubur Kalang dan komunitas pendukungnya.

Apabila dihubungkan dengan berbagai observasi terhadap konsep-konsep religi dan kematian yang masih dapat diidentifikasi dari beberapa Orang Kalang yang masih eksis saat ini, ternyata menunjukkan suatu konsep yang berbeda antara keduanya. Makam-makam Orang Kalang saat ini yang antara lain terdapat di Desa Ngotho, Yogyakarta menunjukkan tradisi penguburan yang berbeda sama sekali dengan tradisi Kubur Kalang, karena direalisasikan sebagai makam Islam pada umumnya. Memang terdapat beberapa unsur supra-natural dalam konsep kematian dan penguburan di Desa Ngotho dengan melaksanakan upacara pelepasan arwah untuk moksa yang disebut dengan Kalang Obong (Lelono, 1989), namun hal ini hanya berhubungan dengan konsep pelepasan arwah secara umum, dan sama sekali tidak mampu dikaitkan dengan Kubur Kalang itu sendiri.

Disini nampak adanya kesenjangan akan informasi Orang Kalang dari lokasi penelitian, yang dapat menghubungkan antara Kubur Kalang dengan masyarakat pendukungnya. Situasi setempat saat ini menunjukkan bahwa eksistensi Kubur Kalang dan pendukung budayanya terpisah dengan mekanisma kehidupan sehari-hari masyarakat sekitarnya. Dengan perkataan lain, tidak terdapat kaitan antara Kubur Kalang dengan masyarakat sekitarnya. Oleh karena itu, masyarakat Kalang yang 
dianggap oleh penduduk setempat sebagai pendukung budaya Kubur Kalang, masih tetap merupakan sebuah misteri yang harus dipecahkan.

Pertanyaan selanjutnya adalah: di manakah permukiman pendukung budaya Kubur Kalang ? Satu hal yang pasti adalah bahwa Kubur Kalang merupakan produk budaya sekelompok masyarakat di masa lalu, yang sebagian pendukung budayanya dapat ditemukan kembali dalam bentuk rangka di dalam kubur mereka dalam jumlah cukup banyak. Kenyataan ini mengharuskan kita untuk berpikir bahwa mereka adalah suatu komunitas yang nyata di masa lalu. Dewasa ini tidak terdapat keterangan tradisi lesan mengenai komunitas ini, dan tidak terdapat pula data arkeologis yang dapat ditemukan di sekitar kompleks kubur. Apakah mungkin permukiman mereka terletak di bagian yang sama dengan lokasi Kubur Kalang yang saat ini ditemukan ? Dalam rangka mencari jawab akan kemungkinan ini, penulis telah melakukan survei secara intensif pada bulan Juli 2003 di lokasi-lokasi sekitar kubur. Hanya saja, pengamatan permukaan terhalang oleh situasi setempat yang merupakan hutan jati, sehingga tidak diperoleh data yang meyakinkan adanya indikasi permukiman kuna di sekitar kompleks kubur. Dalam survei permukaan ini memang ditemukan pecahan gerabah yang cukup banyak, tetapi masih diragukan bahwa temuan tersebut berasal dari suatu permukiman yang sejaman dengan Kubur Kalang. Selain data pecahan gerabah tersebut, tidak pernah ditemukan unsur pemukiman lainnya. Oleh karena itu, berdasarkan data yang diperoleh tidak dapat dinyatakan bahwa permukiman pendukung budaya Kubur Kalang terletak di daerah yang sama dengan keberadaan kompleks Kubur Kalang saat ini.

Apabila dikaitkan dengan konsepsi megalitik yang memandang tempat yang tinggi merupakan tempat para leluhur dan sangat sinkron dengan keletakan setiap kompleks Kubur Kalang di ketiga situs, maka konsep ini menyiratkan terpisahnya tempat penguburan (yang harus ditempatkan di lokasi yang tinggi) dengan areal permukiman pendukung budayanya. Apabila anggapan ini beralasan, maka lokasi permukiman mereka harus dicari di tempat lain di luar lokasi Kubur Kalang, dalam radius yang tidak terlalu jauh. Bisa jadi lokasi permukiman mereka berada di lereng-lereng perbukitan yang dipakai sebagai lokasi kubur, mungkin dibuat dari bahan yang tidak permanen (misalnya kayu), dan tidak tersisa sama sekali saat ini.

Meski demikian, tampaknya permukiman tidak dapat dipisahkan terlalu jauh dari lokasi sumber bahan dasar batuan penyusun kubur. Survei yang telah dilakukan membuktikan adanya dua lokasi sumber bahan: sekitar 3 kilometer dari lokasi Kubur Kalang di Situs Kidangan, dan sekitar 500 meter dari lokasi kubur di Situs Gunung Sigro. Lokasi penambangan bahan dasar tersebut, menjelaskan suatu kerja kolektif masyarakat untuk mengangkut dari sumber bahan ke lokasi kubur. Hal ini didasarkan pada berat setiap lempengan batu penyusun kubur yang beberapa di antaranya mencapai ratusan kilogram. Korelasi antara berat lempengan batu dan jarak yang akan 
ditempuh menghasilkan adanya kerja kolektif. Pada masyarakat megalitik, kerja kolektif merupakan salah satu ciri pokok dari setiap pendirian bangunan megalitik. Hal ini mengakibatkan di antara mereka tercipta suatu tatanan sosial yang solid bagi praktek-praktek ritual dalam pendirian suatu bangunan megalitik. Rumusan kerja kolektif merupakan suatu ciri dominan bagi kelompok mereka, termasuk ketika mereka harus mendirikan kubur-kubur peti batu, yang saat ini tersebar di beberapa tempat di daerah Bojonegoro dan Tuban ini.

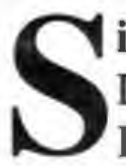
ignifikasi Pertanggalan Absolut Kubur Kalang

Dengan mengacu pada berbagai misteri yang masih menyelimuti eksistensi Kubur Kalang, nampaknya pertanggalan absolut melalui metode Carbon-14 tersebut menjadi sangat berarti. Satu pertanggalan absolut bagi sebaran budaya Kubur Kalang yang sangat banyak memang dirasa kurang memadai, tetapi setidaknya cukup representatif untuk mengetahui periode pasti kompleks Kubur Kalang di Bojonegoro, di mana sampel pertanggalan ini diperoleh. Interpretasi dibawah ini mengandung dua makna, yakni :

$>$ Merupakan pertanggalan absolut yang langsung menunjuk pada usia mutlak salah satu sebaran budaya Kubur Kalang

$>$ Masih harus disikapi "dengan reserve", yang dapat berkembang lagi seandainya diperoleh hasil pertanggalan yang lebih banyak lagi. Pertanggalan absolut tersebut, seperti yang tercantum dalam Bab C, adalah antara tahun 1460 AD dan $1620 \mathrm{AD}$.

Kubur Kalang merupakan salah satu bentuk kubur dari budaya megalitik muda, bukan berasal dari periode prasejarah murni, melainkan merupakan suatu tradisi yang tetap dipertahankan hingga jauh memasuki periode sejarah, paling tidak hingga pertengahan pertama abad 17. Apabila dipakai dasar tahun $1460 \mathrm{AD}$, maka periodisasinya adalah pertengahan abad 15. Hasil ini menunjukkan kesamaan dengan usia beberapa kubur sarkofagus di Bondowoso dan Jember yang berasal dari abad 14 (Hoop, 1938; Heekeren, 1931), dan terdapat pula kubur lainnya yang berasal dari abad 9. Akan halnya kubur peti batu di Wonosari, berdasarkan temuan-temuan artefak logamnya, ditafsirkan berasal dari abad-abad pertama AD. Oleh karenanya, periodisasi berbagai jenis kubur prasejarah tersebut sangat bervariasi, sejaman dengan prasejarah murni dari tingkatan paleometalik hingga masuk dalam periode sejarah.

Dalam kerangka sejarah Indonesia, angka tahun antara 1460 AD hingga 1620 AD akan mengacu pada periode akhir Majapahit dan awal periode Mataram Islam. Angka tahun 1420 AD akan berada pada kurun pemerintahan Bhre Hyang Purwawicesa dari Dinasti Girindrawardhana yang memerintah pada tahun 1456-1466 AD (Hasan Djafar, 1978), sementara angka tahun 1620 AD akan mengacu pada pemerintahan Sultan Agung (1613-1645 AD). Aplikasi pertanggalan absolut dalam peta pemerintahan 
politik di Indonesia tersebut menjadi sangat menarik karena berada pada kisaran peralihan antara kerajaan Hindu dan kerajaan Islam, yang harus dikaitkan dengan situasi sosial masing-masing periode.

Menurut hasil pertanggalan tersebut, siapakah mereka yang dikuburkan dalam kubur peti batu Kubur Kalang ? Untuk mengetahui hal tersebut, sangat menarik meninjau kembali tulisan W.F Stutterheim dalam "Some Remarks on the pre-Hindu's burial Customs in Java" (1956). Dalam tulisan tersebut, Stutterheim membahas berbagai bentuk kubur prasejarah yang terdapat di Indonesia. Sebelum kedatangan budaya Hindu di Indonesia, dan terutama pada masa ketika budaya megalitik mulai tumbuh dan berkembang, masyarakat telah menggunakan kubur megalitik seperti menhir kubur, kubur peti batu, sarkofagus, dolmen kubur, dan bahkan kubur tempayan, untuk menguburkan jasad yang telah meninggal. Tata cara penguburan dalam kubur-kubur megalitik tersebut tidak berhenti begitu saja ketika budaya Hindu mulai masuk dan berkembang di Indonesia. Salah satu bentuk kubur yang mendapatkan perhatian Stutterheim dalam konteks ini adalah menhir kubur, yang mengganggap pendirian menhir dalam suatu kubur adalah sebagai tanda kubur dari seseorang berstatus sosial tinggi yang telah meninggal dunia, sementara rakyat jelata dikuburkan dalam bentuk kubur lainnya, termasuk kubur peti batu. Dalam perkernbangannya setelah budaya Hindu masuk, bentuk kubur menhir tersebut akan diberikan cungkup di atasnya, yang berdinding keras, yang akhirnya secara implisit diwujudkan dalam sebuah candi. Menhir sebagai tanda kubur dari seseorang berstatus sosial tinggi pun mengalami perkembangan setelah Hindu masuk, yang kemudian direalisasi sebagai arca perwujudan dalam bentuk kedewaan dari seorang raja yang telah meninggal dunia, yang menjadi arca utama dalam suatu bilik candi, seperti yang diuraikan dalam "The Meaning of the Hindu-Javanese Candi" (1931). Oleh karenanya, dalam sudut pandang Stutterheim, candi adalah makam raja, arca perujudan mewakili sang raja yang telah meninggal, rohnya kembali ke dewa penitisnya, dan abu jenasahnya telah dicandikan. Lalu, dimanakah kubur-kubur rakyat jelata yang berada di Iuar lingkar keningratan istana kerajaan ? Menurut Stutterheim, rakyat jelata dimakamkan secara bersahaja dengan tetap meneruskan tradisi penguburan prasejarah mereka, dalam hal ini misalnya kubur peti batu.

Meski eksistensi candi dalam visi Stutterheim mendapat tantangan berat oleh Soekmono (1974), namun ada beberapa pernyataan yang sangat sinkron dengan hasil pertanggalan ini. Angka 1420 AD dapat dimasukkan dalam periode Majapahit Akhir yang bernuansa Hindu. Apabila pendapat Stutterheim tersebut benar, maka nampaknya kubur kalang di Bojonegoro tersebut mungkin merupakan bentuk kubur dari penguburan rakyat kebanyakan, yang berkaitan erat dengan kehidupan politis di akhir periode Majapahit. 
Apabila ditinjau berdasarkan angka ekstrim yang lebih muda yakni $1620 \mathrm{AD}$, maka angka tahun tersebut masuk dalam pemerintahan Sultan Agung sebagai raja ketiga di kerajaan Mataram Islam. Oleh karenanya, untuk menginterpretasikan hasil pertanggalan ini dengan kelompok Kalang yang berkaitan dengan masa pemerintahan Sultan Agung akan lebih mudah, seperti yang tercantum dalam Ensiklopedi Indonesia Vol. 3 (1982) : orang Kalang adalah "suku bangsa di Jawa di masa lampau, hidup di hutan-hutan jati di Pegunungan Kendeng Jawa Timur, terutama hidup sebagai penebang kayu. Di masa pemerintahan Sultan Agung dari Mataram, mereka dipaksa tinggal dalam kampung-kampung tertentu. Sejak dahulu, nama Kalang sudah disebut pada batu-batu bertulis". Dalam konteks ini, hasil pertanggalan tersebut akan sangat sinkron dan relevan dengan masyarakat Kalang sebagai bagian kelompok sosial pada masa pemerintahan Sultan Agung, yang saat ini sudah sama sekali lenyap dari daerah setempat.

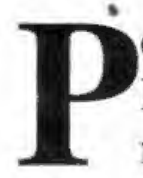

enutup

Persoalan tentang pendukung budaya Kubur Kalang merupakan persoalan rumit untuk dipecahkan. Di satu segi, budaya ini merupakan budaya arkeologi yang menunjukkan bentuk kubur megalitik yang kuat, tetapi di lain segi, data yang ada sangat terbatas untuk dipakai sebagai identifikasi periodisasinya. Penelitian terhadap kubur peti batu yang selama ini dilakukan hanya mampu memberikan pertanggalan relatif, berdasarkan analisis kontekstual dengan temuan artefaktualnya. Penulis telah berupaya mengetahui eksistensi Kubur Kalang di Bojonegoro dan Tuban melalui studi etnografis terhadap kelompok Kalang dan juga orang Samin di daerah setempat menyangkut religi kematian dan tata cara penguburan, tetapi tidak diperoleh sama sekali pertalian antara Kubur Kalang dengan masyarakat yang masih hidup hingga saat ini.

Pertanggalan absolut yang kami lakukan bagi budaya Kubur Kalang di atas merupakan pertanggalan pertama yang diperoleh dari kelompok budaya ini. Hasilnya menunjukkan angka 1420 AD hingga 1620 AD. Ini berarti bahwa Kubur Kalang di Bojonegoro tersebut merupakan suatu tradisi prasejarah, yang masih dipraktekkan oleh sekelompok masyarakat bagi penguburan pada periode tersebut di atas. Apabila pertanggalan tersebut diaplikasikan dalam kerangka sejarah di Jawa, maka angka tertua (1420 AD) akan jatuh pada pemerintahan Bhre Hyang Purwawicesa sebagai salah satu raja dalam Dinasti Girindrawardhana dari akhir periode kerajaan Majapahit, sementara angka termuda (1620 AD) akan menunjuk pada pertengahan pemerintahan Sultan Agung dari kerajaan Mataram Islam. Implikasinya, pendukung budaya Kubur Kalang di Bojonegoro tersebut bisa jadi merupakan kubur dari kelompok rakyat jelata ketika budaya Hindu telah masuk dan berkembang di Indonesia, seperti sinyalemen Stutterheim, atau bahkan bentuk kubur dari kelompok Kalang pada masa pemerintahan Sultan Agung. 


\section{KEPUSTAKAAN}

Ayatrohaedi et al., 1981. Kamus Istilah Arkeologi I. Jakarta : Pusat Pembinaan dan Pengembangan Bahasa, Departemen Pendidikan dan Kebudayaan.

Geldern, R. Von Heine, 1945. "Prehistoric research in the Netherlands Indie", Science and Scientists in the Netherland Indies, Vol. 102. New York: Board for the Netherlands Indies, Surinam, and Curacao.

Handini, Retno, 1998 "Jenis dan Sebaran Kubur Megalitik di Pulau Samosir", Sangkhakala No. IV97-98, Medan, Balai Arkeologi Medan

Handini, Retno, Harry Widianto, Bagyo Prasetyo, 2003. "Kompleks kubur peti batu (kubur kalang di daerah Bojonegoro dan Tuban, Jawa Timur : kaitannya dengan konsep religi kematian dan tata cara penguburan orang Samin dan orang Kalang saat ini", Laporan Penelitian Arkeologi. Bidang Prasejarah, Asisten Deputi Urusan Arkeologi Nasional. Belum diterbitkan.

Hasan Djafar, 1938. Girindrawarddhana : Beberapa Masalah Majapahit Akhir. Jakarta : Yayasan Penerbit Indonesia.

Hassan Shadily, 1982. Ensiklopedi Indonesia Vol. 3. Jakarta : Ichtiar Baru - Van Hoeve dan Elsevier Publishing Projects.

Heekeren, H.R van., 1931. Megalithische overbliifselen in Besoeki, Djawa Vol 11, pp $1-18$.

Hoop, A.N.J Th a Th van der, 1935. "Steenkistgraven in Goenoeng Kidoel", TITLV vol. 75, pp.83-100/

Hoop, A.N.J Th a Th van der, 1938. De praehistorie Geschiedenis van Nederlandsch-Indie, Vol. 1. Amsterdam.

Lelono, H. (1989). Upacara Kalang Obong (Suatu Tinjauan Etno-Arkeologi). Berkala Arkeologi, 10(1), 1-9. https://doi.org/10.30883/jba.v10i1.533

Soekmono, R., 1974. Candi, Fungsi dan Pengertiannya. Desertasi. Universitas Indonesia.

Stutterheim, W.F, 1931. "The meaning of the Hindu-Javanese candi", Journal of the American Oriental Society, Vol. 51, pp. 1-15. 
Stutterheim, W.F, 1956. "Some remarks on the pre-Hindu's burial customs in Java", Studies in Indonesian Archaeology, Translation Serie, K.I.

Sukendar, Haris, 1976. "Bentuk peti batu megalitik di Indonesia", Bulletin Yaperna Tahun II No. 9.

Widianto, Harry, Agus Sudjono, D. Suryanto, 1990. "Sistem penguburan masyarakat megalitik : kajian atas data hasil ekskavasi kubur kalang di Bojonegoro dan Tuban", Analisis hasil Penelitian Arkeologi I, Plawangan : Religi Dalam Kaitannya dengan Kematian, Jilid I. Jakarta : Puslit Arkenas. 